\title{
Biology, feeding potential, standardization of mass production techniques and impact study of Dipha aphidivora Meyrick
}

\author{
MYTHRI $^{1}$, S. PRADEEP ${ }^{2}$ AND S.V. HUGAR*3
}

${ }^{1}$ Raitha Samparka Kendra, Annigeri, DHARWAD (KARNATAKA) INDIA

${ }^{2}$ University of Agricultural and Horticultural Sciences, SHIMOGA (KARNATAKA) INDIA

${ }^{3}$ Agri-Business and Export Knowledge Centre, University of Agricultural Sciences, DHARWAD (KARNATAKA) INDIA

\section{ARITCLE INFO}

Received : 21.03 .2014

Revised : 23.07 .2014

Accepted : 07.08 .2014

\section{KEY WORDS :}

Ceratovacuna laniger, Dipha

aphidivora, Biology, Mass production,

Feeding potential

*Corresponding author:

Email: hugars2000@gmail.com

\begin{abstract}
Experiments were conducted on the biology, feeding potential and standardization of the mass production of Dipha aphidivora Meyrick predator on sugarcane woolly aphid, Ceratovacuna lanigera Zehntner during 2005-2007, at Agricultural Research Station (ARS), Honnavile, Shimoga (district), Karnataka, India. The duration of the first instar was 2.5 to 3.5 days (average $2.95 \pm 0.90$ days). The average duration of second, third, fourth and fifth instar, pupal period, adult female and male moth lasted for $4.57 \pm 1.33,8.30 \pm 1.11,11.37 \pm 2.96$ and $6.10 \pm 0.77$ days, $8.50 \pm 2.15$ days, $4.5 \pm 0.50$ days, $1.5 \pm 0.30$ days, respectively and the total larval period lasted for 24.5 to 39.5 days. The daily consumption rate by $D$. aphidivora was 30.8 aphids per day. D. aphidivora or aphid multiplied faster on 7-month-old crop than 5, 6 and 8 month old crop. At the rate of 50 number of $D$. aphidivora pupae release, highest populations of 4230 per shade net $D$. aphidivora were harvested. Highest populations of $D$. aphidivora were harvested when the shade nets were irrigated once in two days with the population of $4123 \mathrm{D}$. aphidivora per shade net than irrigated once in week with the population of $1490 \mathrm{D}$. aphidivora per shade net. During the experiment, average temperature was $28^{\circ} \mathrm{C}$ and relative humidity was 78 per cent.
\end{abstract}

How to view point the article : Mythri, Pradeep, S. and Hugar, S.V. (2014). Biology, feeding potential, standardization of mass production techniques and impact study of Dipha aphidivora Meyrick. J. Plant Protec., 7(2) : 302-311. 